\title{
A COVID-19 State of Exception and the Bordering of Canada's Immigration System: Assessing the Uneven Impacts on Refugees, Asylum Seekers and Migrant Workers
}

\author{
ZAINAB ABU ALROB \\ Ryerson University, Canada \\ JOHN SHIELDS \\ Ryerson University, Canada
}

\begin{abstract}
Responses to COVID-19 have been characterized by rapid border closures that have transformed the pandemic from a crisis of health to a crisis of mobility. While Canada was quick to implement border restrictions for non-citizens like refugees and asylum seekers, exemptions were made for some migrant groups like temporary workers. The pandemic marked a departure from who is considered worthy of admission to Canada. In fact, the border through restricted and securitized measures has filtered desirable versus non-desirable migrants, creating a hierarchy among migrants within Canada's immigration system by categorizing groups into those deserving versus non-deserving of admission. Deeply embedded societal discrimination and structural inequalities means that COVID-19 has exacerbated the vulnerabilities of migrant groups more than others. COVID-19 has placed an uneven burden on refugees who face increased border restrictions, significant health and safety risks, and limitations in accessing human rights. This paper documents the challenges, social and economic impacts, and exacerbated vulnerabilities border closures have imposed on refugees, asylum seekers and temporary migrants. We assess the many challenges that COVID-19 has created at the intersection of border studies, security resilience and human rights. We employ the conceptual frame of security resilience to critically analyse the dynamics of how and why border strategies have restricted migrant groups in times of crisis and amounted to an unjustified weakening of refugee rights. Finally, we argue that social resilience, which is rooted in rights-based strategies, not only ensures that societies are prepared to meet external shocks and disruptions, but that policy responses mitigate societal discrimination and inequalities. We highlight these strategies as effective mechanisms for reconciling both public health concerns and the rights of migrants to create more cohesive societies in times of crisis.
\end{abstract}


KEYWORDS pandemic border policy; migration; international refugee law; resilience; migrant rights

\section{Introduction}

In response to the spread of COVID-19, forced immobility quickly became a common management tool used by states around the world. While the pandemic is a health crisis, state responses have managed it as a migration crisis by relying heavily on migration management controls (Gagnon, 2020; Sanchez \& Achilli, 2020). Around 219 countries issued blanket border restrictions and over 46,000 travel restrictions by April 2020 (IOM, 2020b; Sanchez \& Achilli, 2020). The reliance on migration control has raised concerns over the short and long-term impacts on migrant groups, in particular, asylum seekers and refugees. The pandemic has created new forms of vulnerability for migrant groups who are facing an uneven COVID-19 impact through high virus transmission, barriers in accessing health care, precarious housing, denial of access to refugee protection, poor and overcrowded living conditions and an increased risk to safety and well-being (Chetail, 2020; Groupe URD, 2020; Shields \& Abu Alrob, 2021). Despite calls from international organizations like the United Nations and the World Health Organization for states to introduce quarantine and health measures for those escaping persecution, states made few exceptions to allow the admission of asylum seekers and refugees (Meer et al., 2020). This left many vulnerable refugees in situations whereby access to safety from persecution is denied. Return to country of origin for many refugees and asylum seekers has negative consequences. Aside from the risk of danger and persecution, risks associated with social stigma, income loss, remaining in overcrowded camps with no access to health care, clean water, or space to quarantine and selfisolate are high (Groupe URD, 2020). While forced immobility has been deemed a necessary health measure, the need to escape persecution was not. In fact, the need for protection from persecution is the apex of essential travel and movement (Perzyna, 2020). Yet, a COVID-19 state of exception and the bordering of migration have prevailed.

During crises, international refugee law provides a guide for state action towards migrant groups, including refugees and asylum seekers. While international law does not specifically outline how states must respond to a health crisis like COVID-19, legally binding principles regarding access to territory for refugees in times of emergency do exist to guide the formulation of state responses. At the core of this is the principle of non-refoulement, whereby the return of refugees to a risk of persecution is prohibited even in the context of a global pandemic. Measures to mitigate health risks resulting from movement across borders would ensure that legal principles of international law are protected, and refugees are not discriminated against nor placed at an increased risk of danger, torture, or persecution (UNHCR, 
2020c). As blanket border measures stand, the global refugee regime confronts an uneven COVID-19 burden, jeopardizing the rights of migrants and placing many of them at a great risk of infection.

This paper aims to contribute to an understanding of the short and longterm implications of COVID-19 on refugee protection. We focus on differential bordering practices that have denied country access to asylum seekers and refugees but awarded access to temporary migrants through selective pandemic border policy. We recognize that it is difficult to predict long-term impacts due to the evolving nature of the pandemic, but our goal is to reflect on how selective bordering practices during the pandemic depart from international norms for refugee protection and human rights. We highlight how bordering practices have resulted in differential inclusion for categories of migrants by relying on border studies and security resilience. We conclude by discussing how social and rights-based resilience strategies that rely on international law can reconcile both public health concerns and the rights of migrants.

Using the concept of security resilience, we assess the state's reliance on migration control to manage a health crisis. Drawing on border studies we offer a critical assessment of how and why border strategies have been used to stratify mobility through hierarchically restricting some migrant groups from admission to Canada. Next, we document border restrictions in Canada and assess the challenges, impacts, and vulnerabilities they have created for refugees, asylum seekers and temporary migrants. We focus our analysis on these three migrant groups to highlight the selectivity of pandemic border policy whereby asylum seekers' mobility is constructed as a threat and used as a justification for exclusions from travel exemptions. International legal frameworks are drawn on to assess how current pandemic policies depart from international law norms for refugee protection and human rights. Government reports and information sources, including Statistics Canada, academic and think tank-based studies, and grey literature from the community sector and civil society, are used to map the challenges COVID19 has created for vulnerable migrant groups. Finally, a social resilience lens is employed to highlight the importance of rights-based strategies for reconciling both public health concerns and the rights of migrants in times of crises.

\section{Security Resilience and the Bordering of Canada's Immigration System: Forced Immobility as a COVID-19 Management Tool}

The concept of resilience has become widely embedded in a range of disciplines to address and react to various external shocks related to health crises, social and urban policy, migration flows, climate change, other environmental disasters, and economic crisis (Brassett \& Vaughan-Williams, 2015; Coaffee \& Fussey, 2015). Resilience is derived from the word resilio, 
which means to "jump back," and was initially formulated to characterize the process of adapting to unexpected events. Psychologists, for example, study whether being resilience is an innate characteristic in individuals or a learned skill (Brassett \& Vaughan-Williams, 2015). Meanwhile environmental scientists use resilience to assess how ecological systems can cope with external events (Bourbeau, 2013). This has resulted in multiple theories that seek to apply resilience to various fields of study. Social scientists for example define it as "the capacity of a social system (for example, an organization, city, or society) to proactively adapt to and recover from disturbances that are perceived within the system to fall outside the range of normal and expected disturbances" (Brassett \& Vaughan-Williams, 2015, p. 33). Various indicators have also been developed for the assessment of resilience in different fields of study (Akbar \& Preston, 2019). Still, the objective of resilience remains consistent across disciplines, including creating conditions to sustain the stability, safety and survival of individuals, institutions, and social systems in the face of external shock events (Cavelty et al., 2015).

In this paper, we understand resilience to be the ability to bounce back and recover after a crisis or external threat. We advocate for resilience-based policy approaches that equip societies with the tools to effectively react, adapt and prevent future disruptions or threats by planning and building resilient strategies that are rights-based (Coaffee \& Fussey, 2015). This is important for mitigating discriminatory and inequitable policy outcomes. Existing studies on migration resilience have analyzed how migrants employ coping skills and community networks to adapt to the challenges of settlement and integration in host societies. Studies have applied resilience as a method of managing the risk of high consequence events (Smith \& Fischbacher, 2009), but not as a tool to analyze the role of border policy in mitigating migration challenges specifically in response to COVID-19. To fill this gap, and to better understand migration resilience in a pandemic era, this paper will draw on conceptualizations of security resilience from international relations studies to understand government rationales behind the forced immobility of migrants. Forced immobility has created a "refuge" crisis within a health crisis. As such, security resilience can help us understand the logic behind state responses to external shocks. The intersection of security resilience and borders speaks to the dynamics of how and why border strategies are applied differently to migrant groups. Further, we identify how state responses that are not able to bridge "the tension between global trends and local impact" can place an uneven burden on already vulnerable groups and jeopardize the recognition of their rights (Pope, 2017, p. 4). 


\section{Security Resilience}

Security resilience is understood to play an important role in riskmanagement, specifically its ability to help societies "prepare for, adapt to and live with a spectrum of possible, perhaps unknowable risks" (Brassett et al., 2013, p. 225). The strategies that governments or other actors choose to employ for adaptation to external shocks depend heavily on how threats are interpreted (Bourbeau, 2013). Consequently, external shocks need to be read and translated as a security threat. At the core of security resilience is the creation of a subject, one that can be blamed and made responsible for the cause of disruptions. Accordingly, responses are organized around how these subjects create vulnerability and expose society to potential harm. Resilience requires a "vulnerable subject to thrive," thus, it "constantly re-produces it" by objectifying and negating the agency of individuals (Cavelty et al., 2015, p. 7). With COVID-19, migrant agency is interpreted as contributing to insecurity. Migrants' mobility, despite border restrictions, profiles them as subjects that fail to abide by pandemic policy and thus cannot be emergency managed. Tropes of migrants bringing in disease through their movement across borders create an image of the state as vulnerable to a migrant threat that is an unforeseeable risk.

The hostility against migrants in health crises often blames displaced people for carrying and spreading diseases (Elias et al., 2020). Ebola is a recent example whereby Haitian people were blamed and stigmatized (Perzyna, 2020). This also happened in the 1900 plague where Chinese people were discriminated against and detained in San Francisco. Similarly, in 1918 the Spanish Flu caused hostility and intolerance towards outsiders (Elias et al., 2020). Meer et al. (2020) note that the medicalised prejudice against migrants was also evident in 1920 in the UK whereby the "Aliens Order" denied refugees admission based on being a health danger. This is also evident in narratives that characterize migration flows as "swamps, likening them to unhuman entities that carry disease" (Meer et al., 2020, p. 6). Accordingly, the nation-state is seen as a single unit that needs protection from an external force that is linked to germs and carries infection through its unmanaged movement (Markel \& Stern, 2002). This perception leads to the scapegoating and stigmatization of "outsiders" whose very existence poses a threat and danger to nation states (Elias et al., 2020; Meer et al., 2020). States react to these threats by mobilizing restrictive and exclusionary measures to protect their polity and remain resilient in the face of danger.

Resilient responses to crisis can be positive or negative depending on their objective. Some suggest that resilience provides a positive value if it seeks to help society "prepare for, withstand, and ultimately improve when faced with extreme events" (Brasset \& Vaughan-Williams, 2015), like building socially resilient communities through rights-based strategies (Bourbeau, 2015). This is seen by security-resilience scholars like Bourbeau (2015) as the bright side of resilience. Meanwhile, the dark side of resilience, or negative resilience, 
aims to organize responses to shock events around threat and uncertainty. This type of resilience places the burden of recovery on the individual (Brasset \& Vaughan-Williams, 2015) and may take on different forms of securitized policy responses.

Bourbeau (2015) notes that negative resilience responses happen after an issue or situation has already been securitized. Of relevance to border practices, he points to "resilience as marginality" as a policy response to external events that does not challenge existing larger immigration or migration policy norms in times of crisis. In other words, novel policy responses are not employed to mitigate a new threat. Rather, these policies expand on existing practices that may forego the rights of specific groups and result in disproportionate consequences as they create deserving versus nondeserving individuals. In the context of COVID-19, border closures announced on March 16, 2020 introduced the return of asylum seekers arriving to Canada from the United States in a temporary border agreement. This policy can be seen as an extension of the existing Safe Third Country Agreement (STCA) where asylum seekers arriving to Canada are sent back to the United States on the basis that it is a "safe" country where refugees can make their claims (Government of Canada, 2020d). While the implications of this controversial policy have been documented in a legal challenge at the Federal Court of Canada they have been further exacerbated for already vulnerable individuals who now are increasingly exposed to COVID-19 through removal. Security resilience helps us understand how the mobility of asylum seekers during the pandemic has been constructed as a threat. This can be characterized as negative resilience whereby one migrant group is excluded from travel exceptions while others are awarded entry. We revisit these restrictions in detail below to discuss their impact.

While government responses to COVID-19 have attempted to create a sense of disease containment through border restrictions, a looming fourth wave extends the state of emergency into the future. As illustrated, resilience directly links security to various "logics of governance" and calls for making "conceptual linkages" to various actors and phenomena (Cavelty et al., 2015). We find that resilience responses in the context of migration all rely on the border to filter out mobility "threats." As such, we explore the intersection of security resilience and borders to more comprehensively understand how borders are being used to create outgroups, like refugees and asylum seekers, from admission to Canada during COVID-19. We note that this has been done through resilience as marginality, whereby states are employing tools already existent within migration management strategies. The importance of social resilience, also known as rights-based resilience, comes to the fore. Social resilience is positive and works to remove the burden of adjustment to crisis from the individual and place it within the collective. It also is grounded in a human rights approach, whereby the rights of all persons irrespective of legal status are protected regardless of the severity of a crisis (Human Rights and Democracy Network, 2017). We turn to the discussion of 
migrant rights under international law at the end of the article, where positive resilience strategies to mitigate the consequences of COVID border policies are highlighted.

\section{Borders and the Creation of Outgroups}

Humanitarian exceptionalism within the context of migrant admission across borders has in recent history been used to distinguish Canada from other countries. The notion that Canada has welcomed and provided a safe haven for refugees has set it up as a leader in the hospitality of those fleeing persecution (Nguyen \& Phu, 2021). This was exemplified when Prime Minister Justin Trudeau emphasized on Twitter that refugees are welcome, after former US President Donald Trump issued what became known as the "Muslim Ban." More recently (August 2021), the Canadian government announced that it would be resettling 40,000 Afghan refugees through a "special immigration program" and a commitment to spend $\$ 350$ million by 2023 (Government of Canada, 2021a; Lau, 2021). Similar to the Syrian Initiative in 2016, Afghan refugees will arrive to Canada as government and privately sponsored refugees. Special consideration is to be given to vulnerable groups including women, LGBTI, and persecuted religious minorities, among others (Government of Canada, 2021a). While this is an example of Canada's humanitarian exceptionalism and human rights approach to global refugee issues, it also represents a state of exception in migration policy. Canada's approach to humanitarianism has limitations in its selectivity in terms of whom it admits or excludes for refuge (Nguyen \& Phu, 2021). This approach is in large measure guided by political considerations and the desire to shape the country's image as a human rights leader, especially in contrast to the US (Nguyen \& Phu, 2021). COVID border responses in Canada are an example of the selectivity used by the government to allow the entry of specific groups of migrants while denying others admission.

In response to COVID-19, blanket border restrictions became a management tool to restrict the admission of people within state boundaries. Border studies as a field is concerned with both physical and material border boundaries as well as their symbolic and social dimensions. Borders are studied as a multi-layered and interlinked phenomenon (i.e., social, political, economic, local, regional, and national processes) (Sevastianov et al., 2015). They can be characterized by their "inherent selectivity," thereby differentiating the right to admission among categories of people (Muller, 2013). Balibar (2002) outlines that the border is a process where controls like health and security checks are used selectively for specific groups of people. Selection processes are applied to those who are suspected of being a risk or threat to society (Muller, 2013). This is known as bordering. Bordering processes can be characterized by the "bounding of territorial identity" based 
on "perceived threats to the nation-state" (Hataley, 2015, p. 100). Boundaries for some identities are thus created in social-political settings and are perpetuated by narratives and discourses. Various theoretical lenses speak to the settings in which differential inclusion is created and sustained. These include neoliberalism, the political economy of migration, racialization theory and the racial state, and many more outside the scope of this paper. While the focus of our attention is on border studies and providing a generalized overview of the creation of outgroups through bordering practices, we acknowledge the role of neoliberal processes in politicizing border measures to divert attention away from issues at the core of COVID19 policy responses. Neoliberal austerity has deepened structural inequalities, especially among vulnerable migrant populations, leaving them in greater danger of COVID-19. The politics of neoliberalism has also helped to produce a clash between evidence-informed versus highly divisive populistoriented pandemic responses, to the detriment of migrants (see Shields \& Abu Alrob, 2021).

Mezzadra and Neilson (2013, p. 7) outline that differential exclusion is a process where borders become tools "of inclusion[/exclusion] that select and filter people" based on "different forms" of movement. Authorized identities are those that have mobility privileges, and include business travelers, economic immigrants, and frequent flyers (Cote-Boucher, 2015). CoteBoucher (2015) argues that in Canada bordering practices are based on xenophilic (foreign language, culture, customs) preferences. These preferences can depend on factors like qualifications, family orientation, wealth or human capital, and are evident in migration policies that privilege a particular migrant group over others in admission to Canada. Examples include federal skilled workers, those who fall under the Canadian experience class, provincial nominee programs, skilled trade workers, caregivers, as well as investors and entrepreneurs. The economic contributions and advantages of these groups privileges their admission. The exemption of temporary migrants to Canada despite blanket border measures can be seen as an extension of this privilege to specific migrant groups. Dauvergne (2008) outlines that "moral worthiness" of specific migrant groups is assessed based on xenophilic imagery. In other words, preferences for specific migrants determine degrees of mobility. Groups are consequently compared to one another. We see this imagery in mutually exclusive dichotomous narratives whereby desirable migrants are played off against "undeserving" and "bogus" refugees taking advantage of political, social and economic institutions (CoteBoucher, 2015). Admission for the former is preferred over the latter. Similar to security resilience discourses, uncertainty is created around the mobility of outsiders. Hence, bordering practices will work to detain, expel, and exclude specific migrant groups. In Canada, the criminal refugee "other" arriving at the border unannounced has been at the centre of migration policies that work to prevent irregular migration (Cote-Boucher, 2015; Perzyna, 2020). Similar discourses are reflected in pandemic border policies that construct asylum 
seekers as threats because of their uncontrolled mobility. Meanwhile, resettled refugees, temporary migrants and immigrants are increasingly admitted in a controlled manner that does not warrant danger or threat.

The exclusion of groups from admission through bordering practices creates hierarchies that stratify migrant groups (Macklin, 2020). In the context of COVID-19, the risk of "outgroups" like asylum seekers has been increasingly emphasized despite the need for refugee protection (Perzyna, 2020). Indeed, the arrival of asylum seekers at borders is a case of the vulnerable attempting to exercise their rights under international law (Macklin, 2004; UNHCR, 2020c). Barreneche (2020) outlines that the pandemic has provided space for political narratives to blame the "other" for external health threats. The mobility of groups is seen as negative and a sign of irresponsibility. Here narratives of the unmanageable resilient subject creating vulnerability are at play. Further, and similar to security resilience, bordering strategies rely on a "villain" to blame for external threats. The state is seen as vulnerable to the threat of COVID through unauthorized mobility. Consequently, asylum seekers' exclusion from admission to Canada, despite their need for protection, is justified and made to be seen as necessary. There are implications to bordering Canada's immigration system and stratifying admission to Canada. We document these implications and analyze their human rights impact below.

The COVID-19 State of Exception: Assessing the Uneven Impacts on Migrant Groups

It is now widely evident that migrant groups have been greatly impacted by COVID-19. Some have been stranded at borders while others have been lost at sea with no means to return to their countries of origin (UNHCR \& IOM, 2020). Despite the pandemic and resulting forced immobility, migration has not stopped. In fact, research suggests that the pandemic has been a growing push factor for people to move across borders (Mixed Migration Centre, 2020). The risks associated with irregular migration have grown in parallel with health threats as countries continue to deport and remove migrants who arrive at border entry points. For example, Mexico's National Institute for Migration reported the deportation of 480 migrants from Honduras, ElSalvador and Guatemala (Sanchez \& Achilli, 2020). Return to country of origin for many refugees and asylum seekers has negative consequences. Aside from the risk of danger and persecution, threats associated with social stigma, income loss, remaining in overcrowded camps or poor living conditions with no access to health care, clean water, or space to quarantine and self-isolate are high (Groupe URD, 2020).

Border controls have long enforced the otherness of refugee groups through narratives that depict them as "bogus" thereby denying their legitimacy. As outlined above, agency and free mobility across borders has 
been used by states as an indication of refugee ingenuity (Osterberg, 2016). Current pandemic policy shows that in times of emergency no exceptions have been made for the most vulnerable in society. This must be addressed through positive resilience, as it jeopardizes the rights of migrant groups and state obligations under international law during times of crisis. The stratification process during the pandemic marks a departure regarding those we consider to be essential to our very survival. Asylum seekers, as we document below, are low on this hierarchy of exemptions (Macklin, 2020). Temporary migrants on the other hand have been highly stratified, moving from unskilled laborers to essential workers exempt from blanket border restrictions due to their necessity to Canada's economy, specifically food security. Resettled refugees, we argue, have been placed in the middle with an initial halting of resettlement later resuming, but with very slow and controlled progress.

\section{Resettlement}

Blanket travel restrictions announced on March 17, 2020 included the complete halting of Canada's resettlement efforts. The United Nations Refugee Agency (UNHCR) and the International Organization for Migration (IOM) announced the temporary suspension of resettlement due to COVID19 (UNHCR, 2020a). Prior to the pandemic, Canada had increasingly advanced resettlement efforts surpassing both the US and UK in 2018 (Radford \& Connor, 2019). Despite federal resettlement targets for 2021 being 36,000, arrivals were suspended (Harris, 2020b). In response to calls to resume resettlement, the office of the Minister of Immigration, Refugees and Citizenship (IRCC) Marco Mendocino outlined that IRCC "will work with partners to continue to resettle refugees" (Omstead, 2020) but failed to indicate firm dates.

The impact of COVID-19 on resettlement is significant. Resettled refugees are those residing in third countries in camps, detention, or other settlements like dense urban centres (Farge \& Paperny, 2020). Those residing in camps are most vulnerable to COVID-19. They are confined to tight spaces with little capacity to social distance, lack of adequate sanitation, medical services, and health care (Ashad, 2020; Hedayet, 2020; United Nations Network on Migration, 2020a). In the Moria Camp in Greece, for example, 1,300 people are forced to share one water source, significantly restricting the capacity to hand-wash (Medecins Sans Frontieres, 2020). The Norwegian Refugee Council (NRC) has reported its inability to reach 300,000 people in the Middle East to deliver humanitarian aid (2020). Similarly, UNHCR has reported challenges in delivering aid to displaced people. These challenges include a collapse in the supply of personal protective equipment (PPE), lack of medical items, restricted methods of transportation due to border closures, flight reductions and quarantine restrictions (Bigg, 2020). Lack of PPE is 
especially critical for health workers on camp sites who cannot treat patients without appropriate COVID-19 health protective measures (Root, 2020). Educational programmes have also been restricted due to COVID-19. UNICEF has been implementing home-based learning programs in Cox's Bazaar, Bangladesh, which is home to one million Rohingya refugees, with the support of the Canadian government (Government of Canada, 2020c). Despite this, refugees report difficulty in adapting. Workers share this concern and note that while remote programs help fill gaps, they do not ultimately address the problem (Government of Canada, 2020c).

In light of the halting of resettlement, refugee advocates have called on the Canadian government to resume resettlement. In June 2020, UNHCR and IOM announced that the temporary hold on resettlement has been lifted (UNHCR, 2020b). Since June, 250 refugees per week are being admitted to Canada under the resettlement program (Harris, 2020b). Travel exemptions have only been awarded to refugees who had been approved by the Canadian government before March 18, 2020 (Desjardins, 2020). The Canadian Refugee Sponsorship Agreement Holders Association (CRSAHA) - which represents 118 Refugee Sponsorship Agreement holders - had called on the Canadian government to extend travel exemptions to "all refugees that are and will be approved for permanent residence in Canada, regardless of their approval date" (Desjardins, 2020). CRSAHA further stressed that refugees remain in vulnerable circumstances with many not only living in poor conditions but also suffering from income loss. NDP MP Jenny Kwan, speaking in support of refugee advocates, outlined that "Canada can lift travel restrictions for refugees while still protecting public health and safety" (Harris, 2020b). The spokesperson for Minister of Immigration Marco Mendocino announced that the Canadian government was "working to identify the most urgent refugee cases as international partners begin to resume operations abroad" (Harris, 2020a). Urgent cases include vulnerability considerations as well as capacity, travel availability and travel limitations (Harris, 2020b).

Resettled refugees - the small number who were partially exempted from blanket travel restrictions - face an uneven COVID-19 burden. FCJ Refugee Centre (2020) outlines that there are delays in family reunification, leaving families separated and in limbo as they wait for sponsorship applications to be approved. One resettled family in St. Johns New Brunswick has been waiting three years to be reunited. Due to COVID-19, flights had been cancelled. Family members remain in camps while awaiting resettlement and in poor conditions until travel is allowed (Walsh, 2020). While the reduction of resettlement to abide by public health measures can be understandable, it is important to ensure that it does not impact long-term settlement efforts. Although limited, the exemptions awarded to resettled refugees are aligned with border narratives that prefer resettlement over asylum arrivals. The Canadian government has grown to favor "resettlement from UN-vetted refugee camps" in its migration policy (Perzyna, 2020). Tropes of agency and 
hopelessness can be juxtaposed here. The handpicking of refugees for resettlement can be seen as a preferred migration management tool that allows states to control admission (Perzyna, 2020). In contrast is the uncontrolled and unprecedented mobility of asylum seekers whose agency and resilience pose a challenge to state control over its borders. In light of this, resettled refugees are resilient subjects whose mobility can be controlled by the state. Thus, they can and are subject to exemptions from border measures.

\section{Temporary Migrants}

Travel exemptions for temporary migrants came after concerns were raised over food insecurity as a result of labour shortages in Canada (Hooper \& Le Coz, 2020). Temporary migrants, particularly from Mexico, Jamaica and the Caribbean are heavily relied on in the agricultural sector (Statistics Canada, 2020). In Ontario alone, 20,000 migrant workers are recruited for planting and harvesting (Dubinski, 2020). On March 21, 2020, in an effort to "maintain" Canada's food security, the government announced travel exemptions for agriculture, fish and seafood workers (Harris, 2020c; Orton, 2020). Those arriving through the Temporary Migrants Program would have their flights arranged by the Ministry of Agriculture (Dubinski 2020). Health measures such as a 14-day quarantine, where employers are required to arrange appropriate living accommodations and monitor the health of migrant workers, were instituted (Dubinski, 2020; Government of Canada, 2020b).

The admission of temporary migrants despite border restrictions marks a departure from who is considered essential and worthy of exemptions. They have been highly stratified among other migrant groups because they are considered essential for the survival of Canada's food as well as other industries (Shields \& Abu Alrob, 2020). Political narratives created a sense of urgency and elevated the status of foreign workers. Words like "essential," "survival," and "security" distinguished migrant workers from other groups as worthy and deserving of admission to Canada to help fight a looming food crisis. Positive resilience was attached to this group in light of their exemptions. A Senate of Canada National Survey (Nanos Survey, 2020) reveals that public opinion towards temporary migrants is positive. The study found that $40 \%$ of Canadians support avenues for migrant workers to remain in Canada, with Atlantic residents holding the highest rates. Further, $56 \%$ of female respondents and $46 \%$ of men also supported granting benefits and protection to migrant workers, including minimum wage protection, health care and workers compensation (Nanos Survey, 2020).

The contribution of essential workers to Canada has indeed paved a pathway to citizenship for them. On May 22, 2020 the federal government announced that non-seasonal workers in meat processing, animal farming (i.e., poultry, cattle), greenhouse and nursery production, may apply for 
permanent residency through the agri-food pilot program (Government of Canada, 2020a). The pathway to citizenship is part of government efforts to recognize the essential contribution of migrant workers and also to "build resilience in the agriculture sector" (Fraser, 2020). While this is a welcome development, there are only 2,700 spots available and some groups like seasonal farm workers and other full year agricultural workers have been excluded from applying (Emmanuel, 2020).

Recognition of the value brought by temporary migrants has occurred without acknowledging their poor living and working conditions. Migrant workers have long reported overcrowded accommodations, with as many as 30 workers forced to share poorly equipped and cramped facilities (Basok \& George, 2020; Kelly, 2020). This along with poor work conditions have exposed foreign workers to COVID-19 at higher rates than the rest of the population. Since their arrival to Canada, reports of outbreaks at nurseries have been plentiful (Rodriguez, 2020).

WES (2020) reported the findings of a study that assessed access to services in Canada among immigrant and migrant groups, including international students and temporary migrants. Unemployment due to COVID-19 was $14 \%$ among temporary migrants. When asked about access to services, $43 \%$ indicated not knowing that they were eligible and only seven percent responded yes when asked if they had contacted a social service agency during COVID-19. Further, 20\% reported not being able to afford their rent, mortgage or utilities. This indicates that while the work of temporary migrants deemed them essential and provided them with an exemption to travel restrictions, they continue to face an uneven COVID-19 burden. Access to health and social assistance are also important to address the inequalities workers face, especially during COVID-19 (United Nations Network on Migration, 2020a). As such, migrant groups including temporary migrants residing in Canada should be able to access social support services like employment insurance, CERB, and social subsidies like child benefits (Guadagno, 2020).

\section{Asylum}

Asylum seekers have arguably faced the greatest impact of COVID-19. The suspension of asylum has weakened the right to international refugee protection and access to fundamental refugee rights (Groupe URD, 2020; United Nations Network on Migration, 2020a). The impacts of these restrictions have exacerbated the vulnerabilities of this migrant group. Some have been stranded at borders and are at an increased risk of persecution (IOM, 2020a). Others have been subject to detention, extended confinement due to COVID-19 and deportation to danger (Groupe URD, 2020). Individuals sent back to the United States by the Canadian government are an example of this. Since March 2020, the Centre for Disease Control and 
Prevention in the US has issued the deportation of any non-citizen arriving to the United States (Lakhani, 2020). To prevent the spread of COVID-19 immigration officers have been authorized to deport and remove asylum seekers (Hernandez \& Miroff, 2020; Meer \& Villegas, 2020). As of April 2020, immigration officers had deported 17,965 asylum seekers including 95 minors, many of whom have tested positive for COVID-19 (Dickerson \& Semple, 2020). The speed at which these deportations occur have been reported to be a mere 96 minutes (Hernandez \& Miroff, 2020). The US's deportation and removal of asylum seekers was criticized by the UN for its violation of international law (Lakhani, 2020). The United Nations Network on Migration (2020b, p. 1) called on states to "suspend forced returns during the pandemic, in order to protect the health of migrants and communities, and uphold the human rights of all migrants, regardless of status." Further, it stressed that asylum seekers face an increased risk of return to danger, torture, and persecution. What is more, the health risks associated with forced returns are high for asylum seekers, immigration, and border officers as well as health care workers, both in country of origin and country of arrival. The health systems of refugee producing countries are lacking in capacity to protect citizens from COVID-19 and mitigate the social and economic issues the pandemic has created (United Nations Network on Migration, 2020a). This is in addition to lack of adequate health systems and poor living and working conditions where sanitary and confinement measures are compromised (UNHCR \& IOM, 2020).

Canada's return of asylum seekers to the US where the risk of detention along with deportation is high poses a threat to the recognition of asylum rights. The US's annual detention population was over 500,000 in 2019, significantly higher than the rest of the world's detention rates combined (Keller \& Wagner, 2020; Perzyna, 2020). It is no surprise that in June 2020, the Federal Court of Canada ruled that the return of asylum seekers through the STCA is in fact impeding their rights. The court cited the return of asylum seekers to the US where detention and denial of access to protection as a violation of section 7 of the Canadian Charter of Rights and Freedoms, whereby the rights to liberty and security are guaranteed (Atak et al., 2021). By extension, the temporary COVID-19 measures to suspend asylum and return individuals to the United States flouts section 7 of the Charter and the principle of non-refoulement under international law.

Significantly, reports of Canada deporting "thousands of people" have begun to emerge (Paperny, 2021). The number of deportations for 2020 was 12,122, the highest since 2015 (Paperny, 2021). In March 2020, Canada paused deportations because of COVID-19, except for cases of serious criminality (Gerster, 2020). However, since November 2020 deportations have resumed. The health risks associated with this are high. Removals involve airport transfer, and enclosure of people with others. The Canadian Association of Refugee Lawyers has criticized the government's actions, 
citing that there is "no indication" that these "removals are essential" (Paperny, 2021).

\section{Against the Backdrop of International Refugee and Human Rights Law: Is Refuge in Crisis?}

The differentiated admission policies granted to migrant groups like temporary migrants versus those for asylum seekers brings to the fore one important question: is refuge in crisis? It is worth noting that despite exemptions both resettled refugees and temporary migrants still face an uneven COVID-19 burden. The halting of asylum warrants our attention as a global community. This urgency comes from the risk of extending emergency measures without an end in sight (Groupe URD, 2020), and with the normalizing of extraordinary policies for groups that need protection in and outside times of crisis. The pandemic also presents an important moment for bringing change and setting the right precedent for the future of refuge. We want to bring to the fore the gravity of blanket border restrictions against asylum seekers by referencing international refugee and human rights law. Both legal and normative frameworks provide a valuable tool to assess the short and long-term impacts of the pandemic. We are in a moment where a refuge crisis looms within a growing health crisis. The measures against refugees and asylum seekers are discriminatory and weaken international norms and standards for refugee protection (FCJ Refugee Centre, 2020). Health risks should be mitigated with appropriate measures like quarantine, self-isolation, and access to vaccinations, thereby allowing governments to manage migration in a safe way that does not pose larger risks to society (FCJ Refugee Centre, 2020).

Legal principles under international refugee and human rights law make evident the lack of justification for differential border restrictions on the grounds of health risks (FCJ Refugee Centre, 2020; UNHCR \& IOM, 2020). Sovereign power awards states the control to regulate admission across their borders. These measures, however, may not result in the denial of the opportunity to apply for refugee protection using legal state avenues or lead to refoulement (return to torture, danger, or persecution) (UNCHR, 2020c). Individuals should be granted the opportunity to have their refugee claim individually assessed. Further, states hold the responsibility to ensure that individuals who are within their territorial boundaries are not subjected to refoulement. There are two levels of legal norms to consider regarding the human rights of migrants. The first are core and fundamental rights that always apply both inside or outside a crisis or emergency. These include the rights to freedom from torture, inhumane treatment, degradation, and the right to life. Particularly applicable to asylum seekers and refugees is protection from refoulement, expulsion, discrimination, and racism (Chetail, 2020). Second are exemptions afforded by select conventions whereby states 
may employ lawful restrictions to rights. For example, freedom of movement can be restricted at border points with the purpose of preventing the spread of COVID-19. However, these restrictions - although lawful - cannot impede on fundamental human rights, specifically the rights of refugees to seek asylum and be individually assessed for their claims (Chetail, 2020; UNHCR, 2020a). In these circumstances alternative measures must accompany restrictions, for example alternatives to detention whereby the risk of COVID-19 in overcrowded facilities is mitigated (Chetail, 2020). Further, legal obligations and considerations for persons accessing territory for the purpose of refugee protection during COVID-19 may - and should - include preventive measures like health screening and quarantine requirements (Guadagno, 2020). This is important for resilient and coherent policy, and also for effective governance of the pandemic (Chetail, 2020; United Nations Network on Migration, 2020a).

Prior to the temporary agreement with the US, Canada had announced that it would screen asylum seekers and require a 14-day quarantine period (Embensadoun, 2020). This was commended by UNHCR as it ensured that asylum seekers had access to protection (Macklin, 2020). This was reversed and justified by Prime Minister Trudeau as a "temporary" response that was "in line with Canada's values on the treatment of refugees and vulnerable people" (Harris, 2020a). As we have documented, the use of migration control as a COVID-19 management tool has not reconciled health and human rights (Chetail, 2020). This can be done using a rights-based lens and with positive social resilience at the core. Chetail (2020) details this as a forward-looking perspective, whereby health considerations and migrant protections are integrated to rethink migration policy. He further argues that the "neglect of human rights is counterproductive and arguably dangerous in addressing the health crisis" for two reasons (Chetail, 2020). The first is that stopping asylum through returns increases the spread of COVID-19 to other populations. Second, it creates incentives for irregular migration avenues where health control is not possible to manage. Sanchez and Achilli (2020) agree with this assessment and outline that border restrictions "will not stop irregular migration or smuggling." They further note that the demand for smuggling services has not diminished during COVID-19. Evidence of this is in the boats that continue to carry people to the Canary Islands and Malta from Libya and other countries (Sanchez \& Achilli, 2020; United Nations Network on Migration, 2020a). The undetected movement of people between borders makes it more difficult to respond to pandemic threats, and increases risks of human trafficking as well as the abuse and exploitation of refugees by smugglers (UNHCR \& IOM, 2020; United Nations Network on Migration, 2020a). These consequences can be mitigated by socially resilient border management tools that both enable regular mobility and protect international refugee and human rights law, while maintaining health protocols (UNHCR \& IOM, 2020). 


\section{Looking Forward: Social Resilience as an Effective Crisis Management Tool}

Social resilience as a positive strategy works to prepare societies to meet external shocks and disruptions, and also to reinstate stability and help communities "emerge stronger" through a rights-based approach (Pope, 2017). At its core are social structures and institutions that work to provide support to community members, thereby allowing them to bounce back from barriers and obstacles caused by an emergency or shock event. Social resilience embraces collectivist and solidarity-based approaches in opposition to individualistic and exclusionary approaches to mitigating the impacts of crises (Preston et al., 2021; Shields \& Abu Alrob, 2020).

Uneven COVID-19 policy impacts on migrant groups threaten access to rights as well as successful integration and social cohesion. They can also threaten the resilience of social infrastructure, create tension between community members and weaken support for political institutions (Shields \& Abu Alrob, 2020). Discrimination, lack of adequate access to healthcare and rights as well as social and financial supports may lead to distrust among migrant groups (Gagnon, 2020; McAuliffe \& Bauloz, 2020). As noted, for migrant groups that have been admitted during the pandemic, uneven COVID-19 impacts are still faced.

This is where social resilience strategies that are rights-based become key not only to mitigating the implications of regressive asylum and refugee policy but to building socially cohesive societies where migrants can successfully settle and integrate. This approach does not allow for policies that burden the individual with coping during public crisis in a manner that violates their human rights (Human Rights and Democracy Network, 2017). The state's responsibility when employing resilient strategies to mitigate external shocks is to continue to secure the rights of all persons, and not to weaken migrant rights for the sake of security or managing health threats.

Social resilience will require the introduction of active policy measures that are committed to addressing precarity and the uneven burden of COVID-19 on migrant groups. The impacts of the pandemic will take time to reverse. Yet, efforts that bring structural reforms are an important policy window of opportunity to invest in response and recovery plans that are inclusive and reduce the inequalities faced by the most vulnerable in society (Blasi, 2020; Shields \& Abu Alrob, 2020). There are seven key characteristics that are identified as positive resilience responses and central to building resilient communities in the face of high consequence events. These emerge from the Rockefeller Foundation (2021) where 100 cities have incorporated policies into their governance strategies that have proven effective for building resilience in response to economic, social, health and physical shock events. Resilient policy strategies include: (1) reflection on how past experiences can better inform policy-making; (2) robust and well-managed systems; (3) ability to accommodate and adapt to shock events; (4) flexibility in the 
adaptation of alternative strategies; (5) integration among different levels of governance; (6) recognition of the value of alternative resources; and (7) prioritizing inclusivity of various stakeholders and community groups in decision-making (100 Resilient Cities, 2019). We focus our attention on multi-stakeholder partnerships and strengthened inclusion of various groups. While all seven strategies are important, these two align with the United Nations Network on Migration (2020a) recommended guidelines on effective COVID-19 "preparedness, prevention and response."

The admission and inclusion of migrants in socio-economic response strategies as well as mitigating barriers in accessing health, social security services and information into policy responses are an important whole-ofgovernment approach to COVID-19. To ensure that these policy strategies are rights- and evidence-based, engagement with migrants and community groups will ensure policy sustainability and effectiveness (United Nations Network on Migration, 2020a). This will bring to the fore the facilitation of inclusive, affordable, non-discriminatory policies that place the rights of migrants at their core and work to protect their rights. Attention should be placed on reversing discriminatory border policies and the vulnerabilities COVID-19 has exacerbated for migrant groups.

\section{Conclusion}

We have documented the many challenges migrant groups disproportionately face due to COVID-19 border policies. Using security resilience and a border lens, we highlight how pandemic policy responses have heavily relied on migration control to manage a health crisis. The bordering of Canada's immigration system hierarchically admits and stratifies groups. Further, we identify the policy developments that pose a threat to the state of refugee protection and a weakening of refugee rights. While border restrictions for some migrant groups like asylum seekers are an extension of migration control before the pandemic, it is evident that human rights have been jeopardized for the sake of crisis management. We recognize that in times of emergency states can restrict some rights, like free movement. However, border policy must take into consideration the human rights that are fundamental to humanity. The shuttering of borders to refuge may not be justified on the grounds of virus contagion. States can reconcile international refugee and human rights law with public health measures. The UNHCR's (2020c) call on states to incorporate health measures at the border and not forego the rights of refugees in seeking protection during the pandemic is significant. The escape from persecution should be the "apex" of exception (Perzyna 2020), not the other way around.

There are Canadian examples of positive resilience strategies that have worked to include migrant groups and recognize their contributions, including the essential frontline work they perform. This is an approach that 
values human capital and the contributions of migrant groups. Temporary migrants are a prime example of this. Yet, their case reveals more than just recognition. Despite their exemption from border measures, they, along with resettled refugees, continue to be vulnerable and carry an uneven COVID-19 burden. This calls for a rights-based model of inclusion that should prevail in both pandemic and post-pandemic policy. While these are extraordinary times, the rights of migrants must not be compromised in the name of temporary or emergency measures.

Social resilience approaches reveal the discrimination and barriers that migrant groups face. In this context, rights-based strategies during a crisis can work as a window of opportunity to create structural and systemic reform that creates constructive alternatives within migration policy and practice based in social justice principles. This is integral to a post-pandemic society that places social justice at the fore and helps to reconcile human rights with effective migration management.

\section{Acknowledgements}

This research was conducted as part of the Building Migrant Resilience in Cities - Immigration et résilience en milieu urbain (BMRC-IRMU), a research partnership in Ontario and Quebec implemented by York University and numerous partners with support from the Government of Canada's Social Sciences and Humanities Research Council Grant \#895-2016-1004. The views expressed in this publication are those of the authors.

\section{References}

100 Resilient Cities (2019). Resilient cities, resilient lives: Learning from the 100RC network. https://resilientcitiesnetwork.org/downloadable_resources/UR/Resilient-Cities-ResilientLives-Learning-from-the-100RC-Network.pdf

Akbar, M., \& Preston, V. (2019). Migration and resilience: Exploring the stock of knowledgeReview of the literature 2000-2016 [Research report]. BMRC/IRMU. https://bmrcirmu.info.yorku.ca/files/2019/06/Immigrants-and-Resilience-Working-Paper_Final.pdf

Ashad, S. B. (2020, May 9). The status of refugees during COVID-19 pandemic. Northeast Now. https://nenow.in/health/status-of-refugees-during-covid-19-pandemic.html

Atak, I., Abu Alrob, Z., \& Ellis, C. (2021). Expanding refugee ineligibility: Canada's response to secondary refugee movements. Journal of Refugee Studies, 34(3), 2593-2612.

Balibar, E. (2002) Politics and the other scene. Verso.

Barreneche, S. B. (2020). Somebody to blame: On the construction of the other in the context of the COVID-19 outbreak. Society Register, 4(2), 19-32.

Basok, T., \& George, G. (2020, April 26). Migrant workers face further social isolation and mental health challenges during coronavirus pandemic. The Conversation. $\mathrm{https}$ ://theconversation.com/migrant-workers-face-further-social-isolation-and-mentalhealth-challenges-during-coronavirus-pandemic-134324

Bigg, M. M. (2020, May 7). The pandemic has stressed production and transportation in unprecedented ways. UNHCR. 
https://www.unhcr.org/news/stories/2020/5/5eb294fb4/pandemic-stressed-productiontransportation-unprecedented-ways.html

Blasi, G. (2020, June 2). There is no recovery without migration. Social Europe. https://www.socialeurope.eu/there-is-no-recovery-without-migration

Bourbeau, P. (2013). Resiliencism: Premises and promises in securitisation research. Resilience, 1(1), 3-17.

Bourbeau, P. (2015). Migration, resilience and security: Responses to new inflows of asylum seekers and migrants. Journal of Ethnic and Migration Studies, 41(12), 1958-1977.

Brassett, J., Croft, S., \& Vaughan-Williams, N. (2013). Introduction: An agenda for resilience research in politics and international relations. Politics, 33(4), 221-228.

Brasset, J., \& Vaughan-Williams, N. (2015). Security and the performative politics of resilience: Critical infrastructure protection and humanitarian emergency preparedness. Security Dialogue, 46(1), 32-50.

Cavelty, M. D., Kaufmann, M., \& Kristensen, K. S. (2015). Resilience and (in)security: Practices, subjects, temporalities. Security Resilience, 46(1), 3-14.

Chetail, V. (2020). COVID-19 and human rights of migrants: More protection for the benefit of all. Internaltional Organization for Migration (IOM), Geneva. https://publications.iom.int/system/files/pdf/covid19-human-rights.pdf

Coaffee, J., \& Fussey, P. (2015). Constructing resilience through security and surveillance: The politics, practices and tensions of security-driven resilience. Security Dialogue, 46(1), 86105.

Cote-Boucher, K. (2015). Bordering citizenship in 'an open and generous society': The criminalization of migration in Canada. In S. Pickering \& J. Ham (Eds.), The Routledge handbook on crime and international migration (pp. 75-90). Routledge.

Dauvergne, C. (2008). Making people illegal: What globalization means for migration and law. Cambridge.

Desjardins, L. (2020, November 2). Sponsors ask Canada to lift refugee travel restrictions. CBC Radio. https://www.rcinet.ca/en/2020/11/02/sponsors-ask-canada-to-lift-refugee-travelrestrictions/

Dickerson, C., \& Semple, K. (2020, April 18). U.S. deported thousands amid Covid-19 outbreak. Some proved to be sick. The New York Times. https://www.nytimes.com/2020/04/18/us/deportations-coronavirus-guatemala.html

Dubinski, K. (2020, March 21). Canada lifts restrictions on foreign workers, including migrant farm laborers. CBC News. https://www.cbc.ca/news/canada/london/canada-lifts-travelrestrictions-for-foreign-workers-1.5505579

Elias, A., Ben, J., Mansouri, F., \& Paradies, Y. (2020). Racism and nationalism during and beyond the COVID-19 pandemic. Ethnic and Racial Studies, 44(5), 783-793.

Embensadoun, (2020, March 17). Asylum seekers irregularly crossing to Canada will be screened. Global News. https://globalnews.ca/news/6689836/asylum-seekers-canadacoronavirus/

Emmanuel, R. (2020, May 19). Advocate warns new agri-food pilot is inaccessible for many critical migrant workers. iPolitics. https://ipolitics.ca/2020/05/19/advocate-warns-newagri-food-pilot-is-inaccessible-for-many-critical-migrant-workers/

Farge, E., \& Paperny, A. M. (2020, March 17). UN to suspend refugee resettlement because of coronavirus. Global News. https://globalnews.ca/news/6690715/un-refugee-coronavirus/

FCJ Refugee Centre (2020). The impact of COVID-19 on refugee claimants and other precarious populations [Powerpoint presentation]. FCJ Refugee Centre. https://www.fcjrefugeecentre.org/wp-content/uploads/2020/10/THE-IMPACT-OF-THECOVID-19-IN-REFUGEE-CLAIMANTS-AND-OTHER-PRECARIOUSPOPULATIONS-FCJ.pdf

Fraser, D. C. (2020, June 1). New pilot program for agri-food labour welcomed. Glacier FarmMedia. https://www.agcanada.com/daily/new-pilot-program-for-agri-food-labourwelcomed

Gagnon, J. (2020, April 2). COVID-19: Consequences for international migration and development. OECD Development Matters. https://oecd-development- 
matters.org/2020/04/02/covid-19-consequences-for-international-migration-anddevelopment/

Gerster, J. (2020, March 18). Canada hits pause on deportations because of coronavirus. Global News. https://globalnews.ca/news/6694503/coronavirus-canada-deportations/

Government of Canada. (2020a). Agri-food pilot: About the pilot. Immigration, Refugees \& Citizenship Canada. https://www.canada.ca/en/immigration-refugeescitizenship/services/immigrate-canada/agri-food-immigration-pilot/about.html

Government of Canada. (2020b). Guidance for employers of temporary migrants regarding COVID-19. Employment and Social Development Canada. https://www.canada.ca/en/employment-social-development/services/foreignworkers/employer-compliance/covid-guidance.html

Government of Canada. (2020c). For refugees, pandemic brings one emergency within another. Global Affairs Canada. https://www.international.gc.ca/world-monde/storieshistoires/2020/refugees_pandemic-refugies_pandemie.aspx?lang=eng

Government of Canada. (2020d, July 23). Canada-U.S. Safe Third Country Agreement. https:/www.canada.ca/en/immigration-refugees-citizenship/corporate/mandate/policiesoperational-instructions-agreements/agreements/safe-third-country-agreement.html

Government of Canada. (2021a, August 13). Canada expands resettlement program to bring more Afghans to safety [News release]. Immigration, Refugees \& Citizenship Canada. https://www.canada.ca/en/immigration-refugees-citizenship/news/2021/08/canadaexpands-resettlement-program-to-bring-more-afghans-to-safety.html

Government of Canada. (2021b). Coronavirus disease (COVID-19): Refugees, asylum claimants, sponsors and PRRA applicants. Immigration, Refugees \& Citizenship Canada. https://www.canada.ca/en/immigration-refugees-citizenship/services/coronaviruscovid19/refugees.html\#claimants

Groupe URD. (2020, May). Migration and the COVID-19 crisis: Current and future impacts. Briefing note \#4. https://www.alnap.org/system/files/content/resource/files/main/Briefingnote-4_Migration_COVID.pdf

Guadagno, L. (2020). Migrants and the COVID-19 pandemic: An initial analysis. IOM Migration Research Series \#60. https://publications.iom.int/system/files/pdf/mrs-60.pdf

Harris, K. (2020a, March 20). Canada to turn back asylum seekers, close border at midnight to stop spread of COVID-19. CBC News. https://www.cbc.ca/news/politics/trudeau-covid19coronavirus-medical-equipment-1.5504149

Harris, K. (2020b, November 12). Refugee advocates say Canada must step up resettlement efforts despite pandemic. CBC News. https://www.cbc.ca/news/politics/refugees-canadapandemic-mendicino-1.5797361

Harris, K. (2020c, March 21). Travel exemptions offered to students, foreign workers as Canada closes border to stop COVID-19. CBC News. https://www.cbc.ca/news/politics/trudeaumarch21-covid19-1.5505540

Hataley, T. (2015). Canada - United States border security: Horizontal, vertical and cross-border integration. Eurolimes, 20, 97-108.

Hedayat, M. (2020, May 26). How are refugees being impacted by COVID-19? Forbes. https://www.forbes.com/sites/mursalhedayat/2020/05/26/how-are-refugees-beingimpacted-by-covid-19/\#3f9c60a38b18

Hernandez, A. R., \& Miroff, N. (2020, April 3). Facing coronavirus pandemic, Trump suspends immigration laws and showcases vision for locked-down border. The Washington Post. https://www.washingtonpost.com/national/coronavirus-trump-immigrationborder/2020/04/03/23cb025a-74f9-11ea-ae50-7148009252e3_story.html

Hooper, K., \& Le Coz, C. (2020, February). Seasonal worker programs in Europe: Promising practices and ongoing challenges. Migration Policy Institute (MPI). https://www.migrationpolicy.org/research/seasonal-worker-programs-europe

Human Rights and Democracy Network. (2017, April). A rights-based approach to resilience: HRDN's input to the EEAS and Commission Joint Communication on Resilience. $\mathrm{https} / / / \mathrm{hrdn} . e u / 2017 / \mathrm{wp}$-content/uploads/2017/04/a-rights-based-approach-to-resilience.pdf

IOM (International Organization for Migration). (2020a). COVID-19 analytical snapshot \#3: Travel restrictions \& mobility - Understanding the migration and mobility implications of 
COVID-19. https://www.iom.int/sites/default/files/our_work/ICP/MPR/covid19_analytical_snapshot_3_-_travel_restrictions_and_mobility.pdf

IOM (International Organization for Migration). (2020b, November). Populations at risk: Implications of COVID-19 for hunger, migration and displacement. IOM \& WFP. https://www.iom.int/sites/default/files/populations_at_risk_-_implications_of_covid19 for hunger migration and displacement.pdf

Keller, A. S., \& Wagner, B. D. (2020). COVID-19 and immigration detention in the USA: time to act. Lancet Public Health, 5, e245-e246. https://www.thelancet.com/pdfs/journals/lanpub/PIIS2468-2667(20)30081-5.pdf

Kelly, A. (2020, April 23). 'System of oppression' puts temporary migrants at risk of COVID-19: advocate. City News. https://www.citynews1130.com/2020/04/23/temporary-foreignworkers-risk-covid-19-advocate/

Lakhani, N. (2020, April 17). US using coronavirus pandemic to unlawfully expel asylum seekers, says UN. The Guardian. https://www.theguardian.com/world/2020/apr/17/usasylum-seekers-coronavirus-law-un

Lau, B. (2021, October 25). Canada promised to take in 20,000-40,000 Afghan refugees. Where are they? National Post. https://nationalpost.com/news/canada/canada-promised-to-take-in20000-40000-afghan-refugees-where-are-they

Macklin, A. (2004). Disappearing refugees: Reflections on the Canada-U.S. Safe Third Country Agreement. Columbia Human Rights Review, 36, 365-426

Macklin, A. (2020, May 6). In Canada: who is really essential? openDemocracy. https://www.opendemocracy.net/en/pandemic-border/canada-who-really-essential/

Markel, H., \& Stern, A. M. (2002). The foreignness of germs: the persistent association of immigrants and disease in American society. The Milbank Quarterly, 80(4), 757-788.

McAuliffe, M., \& Bauloz, C. (2020, April 6). The coronavirus pandemic could be devastating for the world's migrants. World Economic Forum.

https://www.weforum.org/agenda/2020/04/the-coronavirus-pandemic-could-bedevastating-for-the-worlds-refugees/

Medecins Sans Frontieres (2020, March 12). Evacuation of squalid Greek camps more urgent than ever over COVID-19 fears [Press release]. https://www.msf.org/urgent-evacuationsqualid-camps-greece-needed-over-covid-19-fears

Meer, N., \& Villegas, L. (2020, May 27). The impact of COVID-19 on global migration. Governance of the Local Integration of Migrants and Europe's Refugees (GLIMER). https://www.glimer.eu/wp-content/uploads/2020/06/Global-Migration-Policies-andCOVID-19.pdf

Meer, N., Hill, E., Peace, T., \& Villegas, L. (2020). Rethinking refuge in the time of COVID-19. Ethnic and Racial Studies, 44(5), 864-876.

Mezzadra, S., \& Neilson, B. (2013). Border as method, or the multiplication of labour. Duke University Press.

Mixed Migration Centre (2020, December 10). COVID-19 global thematic update \#4: Impact of COVID-19 on the decision to migrate. http://www.mixedmigration.org/wpcontent/uploads/2020/12/154_covid_thematic_update_drivers_and_outlook.pdf

Muller, A. (2013). Territorial borders as institutions: Functional change and the spatial division of authority. European Societies, 15(3), 353-372.

Nanos Survey. (2020). A strong majority of Canadians would support or somewhat support providing a way for temporary foreign workers to remain in Canada. Senate of Canada. https://nanos.co/wp-content/uploads/2020/12/2020-1738-Senator-Omidvar-BlackOctober-Omni-Populated-Report-with-Tabs.pdf

Nguyen, V., \& Phu, T. (2021). Introduction: Critical refugee studies in Canada. In V. Nguyen \& T. Phu (Eds.), Refugee states: Critical refugee studies in Canada (pp. 3-20). University of Toronto Press.

Norwegian Refugee Council (2020, March 25). Covid-19 restrictions preventing thousands from accessing lifesaving aid. https:/www.nrc.no/news/2020/march/covid19-restrictions/

Omstead, M. (2020, April 18). Pause on refugees in Libya detention centres coming to Canada. The Toronto Observer. https://torontoobserver.ca/2020/04/18/pause-on-refugees-in-libyandetention-centers-coming-to-canada/ 
Orton, T. (2020, March 21). Canada to exempt TFW's, employers must isolate workers 14 days. Business in Vancouver. https://biv.com/article/2020/03/canada-exempt-tfws-employersmust-isolate-workers-14-days

Osterberg, E. (2016, June). Social impacts of the securitized arrival experiences of in-Canada refugee claimants. The Canadian Network for Research on Terrorism, Security, and Society Working Paper Series No. 16-09. https:/www.tsas.ca/wpcontent/uploads/2018/03/TSASWP16-09_Osterberg.pdf

Paperny, A.M. (2021, January 22). Canada deporting thousands even as pandemic rages. Reuters. https://www.reuters.com/article/us-health-coronavirus-canada-deportationidUSKBN29R1EL?taid=600ac55ce8fa030001a3c9f8\&utm_campaign=trueAnthem:+Trend ing+Content\&utm_medium $=$ trueAnthem\&utm_source $=$ twitter

Perzyna, M. (2020). The substance of solidarity: What the response to the COVID-19 pandemic says about the global refugee regime. Ryerson Centre for Immigration and Settlement (RCIS) and the CERC in Migration and Integration, Working Paper 2020/15.

https://rshare.library.ryerson.ca/articles/journal_contribution/The_Substance_of_Solidarity What_the_Response_to_the_COVID-

19_Pandemic_Says_About_the_Global_Refugee_Regime/14636520

Pope, A. (2017). Building more resilient communities: Responding to irregular migration flows. The Atlantic Council of the United States.

Preston, V., Shields, J., \& Akbar, M. (2021). Migration and resilience in urban Canada: Why social resilience, why now? Journal of International Migration and Integration. https://doi.org/10.1007/s12134-021-00893-3

Radford, J., \& Connor, P. (2019, June 27). These are the countries that accept the most refugees in the world. World Economic Forum. https://www.weforum.org/agenda/2019/06/canadanow-leads-the-world-in-refugee-resettlement-surpassing-the-u-s/

Rockefeller Foundation. (2021). 100 Resilient Cities. https://www.rockefellerfoundation.org/100resilient-cities/

Rodriguez, M. (2020, May 11). COVID-19 outbreak declared over at Okanagan agricultural business. Nelson Star. https://www.nelsonstar.com/news/covid-19-outbreak-declared-overat-okanagan-agricultural-business/

Root, R. (2020, April 3). Here's what the COVID-19 response looks like in refugee camps. Devex. https://www.devex.com/news/here-s-what-the-covid-19-response-looks-like-inrefugee-camps-96874

Sanchez, G., \& Achilli, L. (2020, May). Stranded: The impacts of COVID-19 on irregular migration and migrant smuggling [Policy brief]. Migration Policy Centre. https://cadmus.eui.eu/bitstream/handle/1814/67069/PB_2020_20_MPC.pdf?sequence=1\&i sAllowed $=y$

Sevastianov, S. V., Laine, J.P., \& Kireev, A.A. (Eds.) (2015). Introduction to border studies. Dalnauka.

Shields, J. and Zainab Abu Alrob, Z. (2021). The Political Economy of a Modern Pandemic: Assessing Impacts of COVID-19 on Migrants and Immigrants in Canada. Alternate Routes: A Journal of Critical Social Research, Vol. 32(1), 137-161.

Shields, J., \& Abu Alrob, Z. (2020). COVID-19, Migration and the Canadian immigration system: Dimensions, impact and resilience [Research report]. BMRC/IRMU. https://bmrcirmu.info.yorku.ca/files/2020/07/COVID-19-and-Migration-Paper-Final-Edit-JS-July-241.pdf?x82641

Smith, D., \& Fischbacher, M. (2009). The changing nature of risk and risk management: The challenge of borders, uncertainty and resilience. Risk Management, 11(1), 1-12.

Statistics Canada. (2020, April 17). COVID-19 disruptions and agriculture: Temporary migrants. https://www150.statcan.gc.ca/n1/pub/45-28-0001/2020001/article/00002-eng.htm

UNHCR. (2020a, March 17). IOM, UNHCR announce temporary suspension of resettlement travel for refugees [Press release]. https://www.unhcr.ca/news/iom-unhcr-announcetemporary-suspension-of-resettlement-travel-for-refugees/

UNHCR. (2020b, June 18). Joint statement: UN refugee chief Grandi and IOM's Vitorino announce resumption of resettlement travel for refugees [press release]. 
https://www.unhcr.org/news/press/2020/6/5eeb85be4/joint-statement-un-refugee-chiefgrandi-ioms-vitorino-announce-resumption.html

UNHCR. (2020c, March 16). Key legal considerations on access to territory for persons in need of international protection in the context of the COVID-19 response. https://www.refworld.org/docid/5e7132834.html

UNHCR \& IOM. (2020). COVID-19: Access challenges and the implications of border restrictions. https://reliefweb.int/report/world/covid-19-access-challenges-andimplications-border-restrictions

United Nations Network on Migration. (2020a). Enhancing access to services for migrants in the context of COVID-19 preparedness, prevention, and response and beyond.

https://migrationnetwork.un.org/sites/default/files/docs/final_network_wg_policy_brief_co vid-19_and_access_to_services_1.pdf

United Nations Network on Migration. (2020b). Forced returns of migrants must be suspended in times of COVID-19.

https://migrationnetwork.un.org/sites/default/files/network_statement_forced_returns_13_may_2020.pdf

Walsh, A. (2020, July 8). N.L. refugees enduring long family separations, due to COVID-19 delays. CBC News. https://www.cbc.ca/news/canada/newfoundland-labrador/pandemicpause-refugees-canada-1.5640083

WES (World Education Services). (2020, December). Impact of COVID-19 on the economic well-being of recent migrants to Canada: A report on survey results from permanent residents, temporary migrant, and international students in Canada.

https://knowledge.wes.org/rs/317-CTM-316/images/wes-research-report-covid-19-recentimmigrants-in-Canada.pdf 